\title{
The Effect of Temperature During Retail Display on the Colour Stability of CO Pretreated Vacuum Packaged Beef Steaks
}

\author{
Lauren Anne Van Rooyen
}

Teagasc

Paul Allen

Teagasc

Eimear Gallagher

Technological University Dublin

See next page for additional authors

Follow this and additional works at: https://arrow.tudublin.ie/schfsehart

Part of the Food Science Commons

\section{Recommended Citation}

Van Rooyen, L., Allen, P., Gallagher, E., \& O'Connor, D. (2018). The effect of temperature during retail display on the colour stability of CO pretreated vacuum packaged beef steaks. Meat Science, vol.145, pp.16-22. https://doi.org/10.1016/j.meatsci.2018.05.017

This Article is brought to you for free and open access by the School of Food Science and Environmental Health at ARROW@TU Dublin. It has been accepted for inclusion in Articles by an authorized administrator of ARROW@TU

Dublin. For more information, please contact

arrow.admin@tudublin.ie, aisling.coyne@tudublin.ie, gerard.connolly@tudublin.ie.

Funder: Department of Agriculture, Food and the Marine

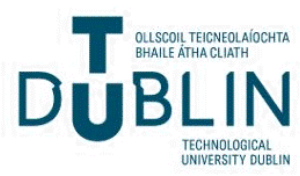




\section{Authors}

Lauren Anne Van Rooyen, Paul Allen, Eimear Gallagher, and David I. O'Connor

This article is available at ARROW@TU Dublin: https://arrow.tudublin.ie/schfsehart/281 


\title{
The effect of temperature during retail display on the colour stability of CO pretreated vacuum packaged beef steaks
}

\author{
Lauren Anne Van Rooyen ${ }^{\mathrm{a}, \mathrm{b}}$, Paul Allen ${ }^{\mathrm{a}}$, Eimear I. Gallagher ${ }^{\mathrm{b}}$, David I. O'Connor ${ }^{\mathrm{b}, *}$ \\ ${ }^{a}$ Teagasc Food Research Centre, Food Quality and Sensory Department, Ashtown, Dublin 15, Ireland \\ ${ }^{\mathrm{b}}$ Dublin Institute of Technology, School of Food Science and Environmental Health, Cathal Brugha Street, Dublin 1, Ireland
}

\section{A R T I C L E I N F O}

\section{Keywords:}

Carbon monoxide

Colour stability

$K / S$ ratios

Meat quality

Packaging

Vacuum packaging

\begin{abstract}
A B S T R A C T
The effect of CO pretreatments applied to beef striploin steaks (Longissimus thoracis et lumborum, LTL) prior to vacuum packaging and display temperature on colour stability, shelf life and tenderness was determined. Steaks were exposed to $5 \% \mathrm{CO}, 60 \% \mathrm{CO}_{2}$ and $35 \% \mathrm{~N}_{2}$ for 3 (CO3), 5 (CO5) or 7 (CO7) h, followed by 28 days display at $2{ }^{\circ} \mathrm{C}$ (good industry practice) or $6{ }^{\circ} \mathrm{C}$ (mild abuse). CO5 was the optimum exposure time as it induced the desirable colour while not retaining the bright colour, irrespective of display temperature. $K / S$ ratios confirmed that CO pretreatment did not mask spoilage and could be more sensitive than colour parameters at monitoring discoloration as colour was not retained. Exposure to $\mathrm{CO}$ did not have any negative effect on meat quality attributes, while mild temperature abuse $\left(6^{\circ} \mathrm{C}\right)$ increased purge loss and decreased $\mathrm{pH}$.
\end{abstract}

\section{Introduction}

Consumer discrimination against discoloured meat products is one of the leading causes of meat waste for retailers in Europe, North America and Industrialized Asia (FAO, 2016).This is mainly due to consumers relying on colour as a cue for perceived quality (Issanchou, 1996) and association with discoloured meat as unwholesome (Faustman \& Cassens, 1990) or unsafe to consume (Grebitus, Jensen, \& Roosen, 2013). Adding to this, the global population is forecasted to continue to increase from 7.5 billion to 9.7 billion by 2050, driving a greater demand for meat supplies. For these reasons, it is vitally important to reduce or remove meat wastage altogether in order to ensure global food supply and a sustainable future for our growing population.

Packaging can play a key role in preventing meat waste by maintaining an attractive colour and avoiding unnecessary consumer discrimination. Innovations in meat packaging technologies which ensure the meat has a desirable "cherry" red colour and support increasing consumer demand and expectation for more tender, high quality meat may be a potential solution (Van Rooyen, Allen, \& O'Connor, 2017). One packaging technology in particular which could meet the above criteria is the application of low concentrations of carbon monoxide (CO) as a pretreatment prior to vacuum packaging. $\mathrm{CO}$ has the ability to act as colour enhancer and coupled with vacuum packaging extends the shelf-life and avoids any negative quality issues associated with high oxygen modified atmosphere packaging (MAP) including tenderness (Van Rooyen, Allen, Crawley, \& O'Connor, 2017). CO is currently used as a primary packaging gas at low concentrations $(0.4 \%)$ or as a secondary packaging gas in the USA (FDA, 2004). In Canada, New Zealand and Australia CO is permitted to be used as a processing aid or secondary packaging gas (Federal Register of Legislative Instruments, 2014; USDA-FSIS, 2016). However, globally the regulation of the use of $\mathrm{CO}$ in meat packaging varies and within the EU CO is currently prohibited. This was at least partly due to concerns that CO may be misused to mask meat spoilage for meat that has previously been stored under inappropriate storage conditions such as elevated temperatures (European Commission, 2001). However, recently Van Rooyen, Allen, Crawley, and O'Connor (2017) showed that the CO pretreatment exposure time can be reduced to $5 \mathrm{~h}$ to enhance colour while allowing discolouration to occur by the use-by-date. Therefore, colour could continue to be used as an indicator of freshness and wholesomeness as the colour would not mask meat spoilage or falsely mislead consumers. However, if this technology was to be implemented within the meat industry further research is necessary to determine the stability of $\mathrm{CO}$ pretreatments, in the case of mild temperature $\left(6^{\circ} \mathrm{C}\right)$ abuse, which may occur due to mishandling during distribution or storage, as temperature has a direct influence on colour stability (O'Keefe \& Hood, 1980).

\footnotetext{
* Corresponding author.

Email address: david.i.oconnor@dit.ie (D.I. O'Connor)
} 
It is therefore necessary to establish that CO pretreatment would not mask meat spoilage under these conditions.

Quantifying the amount of carboxymyoglobin ( $\mathrm{COMb}$ ) present on the meat surfaces at the end of the shelf-life may be useful to confirm that $\mathrm{CO}$ does not mask spoilage by retaining the bright colour. However, quantifying $\mathrm{COMb}$ using reflectance methodology is difficult as currently there is no direct method to quantify COMb (AMSA, 2012). The method of Krzywicki (1979) uses the reflectance values on the meat surface to calculate the proportion of myoglobin in the redox form, however this method does not account for the presence of COMb (AMSA, 2012). The percentages of myoglobin in its various forms can also be calculated from $K / S$ ratios (absorption $(K)$ and scattering coefficients (S)) following Stewart, Zipser, and Watt (1965). The entire meat surface is converted to each of the myoglobin redox states and these standards along with the $K / S$ ratios to determine the percentage of each pigment present at the meat surface. However, unrealistic data are often observed with values lower than $0 \%$ or $>100 \%$ (Mancini, Hunt, \& Kropf, 2003). Mancini et al. (2003) reported that adjusting the data may be useful to obtain more realistic results, however there has been no research to support the benefits of this. Therefore $K / S$ ratios are useful for estimating myoglobin redox forms and give a more detailed understanding of surface meat colour stability. Surface reflectance data are converted to $K / S$ ratios by using the light absorbance $(K)$ and scattering properties $(S)$ using the Kubelka-Munk equation as it relates to reflectance, $\mathrm{R}\left((1-R)^{2} \div 2 R\right)$ which results in more linear data (Mancini et al., 2003). Additionally, $K / S$ ratios may be a useful method to detect the amount of COMb, metmyoglobin (MMb) or deoxymyoglobin (DMb) present on the meat surface (AMSA, 2012), especially at the end of storage to confirm that $\mathrm{CO}$ does not mask spoilage. There are also no reports on the effect of $5 \%$ CO pretreatments prior to vacuum packaging beef steaks on the reflectance and absorbance properties of meat surfaces. Therefore, the objective of this study was to investigate the effect of CO exposure time and temperature on the colour stability and quality attributes including $\mathrm{pH}$, purge loss, $\mathrm{COMb}$ layer, tenderness and cooking loss of beef striploin (LTL) steaks during storage $\left(2^{\circ} \mathrm{C}\right.$ or $\left.6^{\circ} \mathrm{C}\right)$.

\section{Materials and methods}

\subsection{Sample preparation and pretreatment procedure}

CO pretreatments were carried out as described in Van Rooyen, Allen, Crawley, and O'Connor (2017) with minor modifications. Four boneless beef loins (Longissimus thoracis et lumborum, LTL) of normal pH5.43-5.56 from two Charolais-cross (CHX) heifers aged 21-29months of age were obtained from a commercial meat producer for each of the three replicates repeated on three separate occasions. Steaks were cut (25mm thick, $285.2 \mathrm{~g}$ - 388.0 g) at 6-8days post-mortem from each of the four loins (blocks) and one steak from each loin was allocated to treatments randomly. Steaks were vacuum packaged (New Diamond Vac J-V006W, Heavy Duty Automatic Vacuum Machine, Jaw Feng Machinery Co., Ltd, Taiwan; vacuum pressure $<0.01$ Torr held for $32 \mathrm{~s}$ ) in a pouch (5-layer coextruded film with PA/Tie/PE/Tie/PE (OTR: $<-70 \mathrm{~cm}^{3} \mathrm{O}_{2} / \mathrm{m}^{2} / 24 \mathrm{~h}$ at $23^{\circ} \mathrm{C}$ and $50 \% \mathrm{RH}$, Versatile Packaging, Ltd., Castleblayney, Co. Monaghan, Ireland) for $1 \mathrm{~h}$ to allow reduction of the myoglobin to occur and limit the formation of oxymyoglobin. Samples were then exposed to a gas mixture with CO (5\% CO, $60 \% \mathrm{CO}_{2}$ and $35 \% \mathrm{~N}_{2}$ ) or without CO (Control) $(60 \%$ $\mathrm{CO}_{2}$ and $40 \% \mathrm{~N}_{2}$ ) for 3 (CO3 and CONT3), 5 (CO5 and CONT5) or $7 \mathrm{~h}$ (CO7 and CONT7), and stored at $2{ }^{\circ} \mathrm{C}$. They were then removed and immediately individually vacuum packed (Product \# S303, Synpac, PA/PE (OTR: $<38 \mathrm{~cm}^{3} \mathrm{O}_{2} / \mathrm{m}^{2} / 24 \mathrm{~h}$ at $23^{\circ} \mathrm{C}$ and $0 \% \mathrm{RH}$, Synpac Ltd., Saxon way, Priory Park West, Hessle, East Yorkshire, UK). This was placed under retail display at $2^{\circ} \mathrm{C}$ which is good industry practice or $6^{\circ} \mathrm{C}$ which is mild abuse for $28 \mathrm{~d}$ under continuous fluorescent lighting (Meat - Fluorescent Touchcoat T5F18WT8 176 Foodstar Meat Toughcoat, Havells Sylvania Fixtures UK, Ltd) (2115lx) to simulate retail conditions. Temperature was recorded every five minutes using dataloggers (Lascar EasyLog-USB, Lascar Electronics Ltd., Salisbury, SP5, UK).

\subsection{Instrumental colour measurement}

Surface colour measurements, reflectance and absorbance readings were performed using a HunterLab UltraScan Pro (Hunter Associates Laboratory., Inc., Reston, VA) with a viewing port of $25 \mathrm{~mm}$ and illuminant $\mathrm{D}_{65}, 10^{\circ}$ with the specular component excluded. Calibration was carried out using a white standard tile $(\mathrm{L}=100)$ and a light trap $(\mathrm{L}=0)$ covered with the vacuum packaging film to eliminate any effect on the colour readings of packaged steaks. Triplicate measurements were recorded at representative locations on the meat surface for each steak. Chroma $\left(C^{*}=\left(a^{* 2}+b^{* 2}\right)^{1 / 2}\right)$ values were calculated using CIE $\mathrm{a}^{*}$ (redness) and b* (yellowness) measurements. Three surface reflectance and absorbance measurements were also measured from 400 to $700 \mathrm{~nm}$ ( $5 \mathrm{~nm}$ interval). Surface reflectance data at $474,525,572 \mathrm{~nm}$ were calculated by linear interpolation. $K / S$ ratios were determined using the Kubelka-Munk equation to obtain each myoglobin redox form with better linearity (AMSA, 2012). Deoxymyoglobin (DMb) $\left(K / S_{474}\right) /$ $\left(K / S_{525}\right)$, Metmyoglobin $(\mathrm{MMb})\left(K / S_{572}\right) /\left(K / S_{525}\right)$ and Carboxymyoglobin $(\mathrm{COMb})\left(K / S_{610}\right) /\left(K / S_{525}\right)$ were calculated. Reference standards for $100 \% \mathrm{MMb}, \mathrm{DMb}, \mathrm{COMb}$ were prepared (AMSA, 2012). Surface colour analysis was measured at days $0,2,10,21$ and 28.

\subsection{Measurement of $\mathrm{pH}$}

The $\mathrm{pH}$ of each treated steak was measured after removal from the vacuum package using a glass probe $\mathrm{pH}$ electrode (Thermo Scientific $\mathrm{pH}$ meter 420A, Orion Research Inc.) and triplicate measurements were recorded for each steak. $\mathrm{pH}$ measurements were recorded after storage $\left(2{ }^{\circ} \mathrm{C}\right.$ or $\left.6^{\circ} \mathrm{C}\right)$ on days $0,2,10,21 \& 28$.

\subsection{Carboxymyoglobin (COMB) depth}

Carboxymyoglobin (COMb) layer was measured according to the method of (Raines \& Hunt, 2010) to determine the COMb layer on each treated sample. Treated steaks were removed from the vacuum packages after storage, cut in half vertically and the depth of the transition point of $\mathrm{COMb}$ to $\mathrm{DMb}$ was immediately recorded using a digital caliper (Draper Expert, PVC 150 D, Draper Tools Ltd., Hampshire, SO53, UK). Triplicate measurements were recorded in separate locations on each sample and averaged to determine the depth of the COMb layer. COMb layer measurements were measured after storage $\left(2^{\circ} \mathrm{C}\right.$ or $\left.6^{\circ} \mathrm{C}\right)$ on days $0,2,10,21$ and 28.

\subsection{Purge loss}

Purge loss, also known as drip loss or water holding capacity, was determined according to the method of Krause, Sebranek, Rust, and Honeyman (2003) as an index of loss of water from the meat. The weight of each unopened treated steak package was recorded. Each sample was then removed from the package and blotted dry and reweighed to determine weight loss. Purge loss measurements were recorded after storage $\left(2^{\circ} \mathrm{C}\right.$ or $\left.6^{\circ} \mathrm{C}\right)$ on days $0,2,10,21$ and 28 . The percentage purge loss was determined according to the following equation as a percentage of the weight of the steak in the package. With 
this formula the weight of the package is counted as purge loss.

$\%$ Purge loss

$=\frac{(\text { Weight of package }+ \text { steaks })-(\text { Weight of steaks }) \times 100}{(\text { Weight of package }+ \text { steaks })}$

\subsection{Determination of cooking loss}

Determination of cooking loss was according to the method of Shackelford et al. (1991) and as described Van Rooyen, Allen, Crawley, and O'Connor (2017). Cooking loss was determined on samples that had been displayed at $2^{\circ} \mathrm{C}$ or $6^{\circ} \mathrm{C}$ for $0,7,14,21$ and 28 days. Control samples were only analysed after 0 and $28 \mathrm{~d}$ storage due to limited sample size.

\subsection{Warner Bratzler shear force}

Determination of Warner Bratzler Shear Force (WBSF) was performed following the procedure of AMSA (1995) and Wheeler, Shackelford, and Koohmaraie (1997) as described by (Van Rooyen, Allen, Crawley, \& O'Connor, 2017). WBSF was measured on cooked steaks that had used for the determination of cooking loss, displayed $\left(2^{\circ} \mathrm{C}\right.$ or $\left.6^{\circ} \mathrm{C}\right)$ for $0,7,14,21$ and $28 \mathrm{~d}$. Control samples were only assessed after 0 and $28 \mathrm{~d}$ storage due to limited sample size. WBSF was measured using an Instron Universal Testing Machine (Instron Model 5543 (UK) Ltd., High Wycombe, UK), with a load cell of 500 Newtons (N) and a cross head speed of $5 \mathrm{~cm} / \mathrm{min}^{-1}$. Eight cores were taken from each steak parallel to the muscle fibre direction. After eliminating the highest and lowest values the average of the remaining 6 cores was used to calculate the results from each sample, expressed in $\mathrm{N}$ using Bluehill software.

\subsection{Statistical analysis}

Data were analysed using a complete randomized block design with the loin being analysed as a statistical block (SAS ver. 9.3, SAS Institute Inc., Cary, NC, USA). ANOVA (PROC GLIMMIX) was used to carry out a $3 \times 2 \times 5$ split plot factorial design with three exposure times $(3 \mathrm{~h}, 5 \mathrm{~h}$, $7 \mathrm{~h})$, two display temperatures $\left(2^{\circ} \mathrm{C}, 6^{\circ} \mathrm{C}\right)$ and five storage times $(0 \mathrm{~d}, 2$ $\mathrm{d}, 10 \mathrm{~d}, 21 \mathrm{~d}, 28 \mathrm{~d}$ ) as fixed effects and the replicate as a random effect for colour, $\mathrm{pH}$, purge loss and $\mathrm{CO}$-penetration depth. Cooking loss and WBSF analysis were analysed separately using two types of models using ANOVA (PROC GLIMMIX) to carry out a $3 \times 2 \times 5$ split plot factorial design (Model 1 ) with three exposure times $(3 \mathrm{~h}, 5 \mathrm{~h}, 7 \mathrm{~h}$ ), two display temperatures $\left(2^{\circ} \mathrm{C}, 6^{\circ} \mathrm{C}\right)$ and five storage times $(0 \mathrm{~d}, 2 \mathrm{~d}, 10 \mathrm{~d}, 21 \mathrm{~d}, 28$

a)

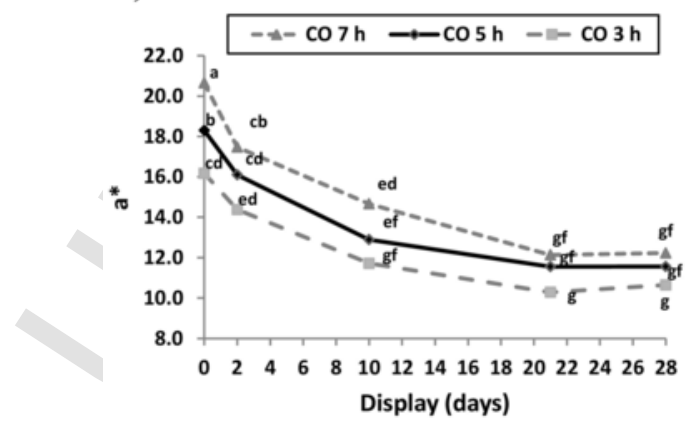

d), as fixed effects and the replicate as a random effect or a $6 \times 2 \times 2$ split plot factorial design (Model 2) with six exposure times (Control $3 \mathrm{~h}$, Control $5 \mathrm{~h}$, Control $7 \mathrm{~h}, \mathrm{CO} 3 \mathrm{~h}, \mathrm{CO} 5 \mathrm{~h}, \mathrm{CO} 7 \mathrm{~h}$ ), two display temperatures $\left(2^{\circ} \mathrm{C}, 6^{\circ} \mathrm{C}\right)$ and two storage times $(0 \mathrm{~d}, 28 \mathrm{~d})$. Where factors were significant, differences between means were determined using Tukey's multiple comparisons test with $P<.05$. The entire experiment was repeated three times.

\section{Results and discussion}

\subsection{Instrumental surface colour analysis}

\subsection{1. $a^{*}$ values}

An exposure time $\times$ display day interaction was observed for $\mathrm{a}^{*}$ values $(P<.01)$ with the difference between exposure times diminishing with storage time (Fig. 1a). Increased exposure time increased redness $(P<.001)$. There was no temperature interaction evident for $\mathrm{a}^{*}$ values $(P>.05)$. CIE a* values decreased over the display period, with the exposure time of $5 \mathrm{~h}$ (CO5) being the optimum to induce redness, while allowing discoloration by the use-by date, in agreement with (Van Rooyen, Allen, Crawley, \& O'Connor, 2017). The threshold used to determine an unacceptable level of discoloration from the instrumental surface colour analysis was $\mathrm{a}^{*}=12$. MacDougall, Down, and Taylor (1986), reported that a $C^{*}$ value of 16 is the limit of acceptability using a Hunterlab and an illuminant D and this value is comparable to an $\mathrm{a}^{*}$ value of 12 . Mean a* values for $\mathrm{CO} 5$ at day 28 were 11.6 i.e. just below the colour threshold. This result means that the colour of CO-pretreated steaks could continue to be used as a reliance quality cue of product freshness by consumers, even after mild temperature abuse $\left(6^{\circ} \mathrm{C}\right)$, as this did not affect colour stability.

\subsubsection{Chroma values}

Chroma is a measure of the colour intensity of meat. As previously mentioned, MacDougall et al. (1986), reported that a chroma value of 16 represents the limit of acceptability and values below 14 are discoloured and considered brown. Consumers may also reject meat products which contain $40 \%$ metmyoglobin ( $C^{*}>14$ ) (Greene, Hsin, \& Zipser, 1971). Chroma values increased with increased exposure time to $\mathrm{CO}(P<.001)$, with mean values on $\mathrm{d} 0$ ranging from 18.7 (CO3) to 23.5 (CO7), and decreased over the storage period $(P<.001)$ (Fig. 1b). There was no temperature effect for chroma values $(P>.05)$. All treatments were above $C^{*}=14$ on day 28 and were therefore considered to be discoloured. Mean $C^{*}$ values on day 28 for $\operatorname{CO} 5\left(C^{*}=15.1\right)$ were just below the limit of acceptability.

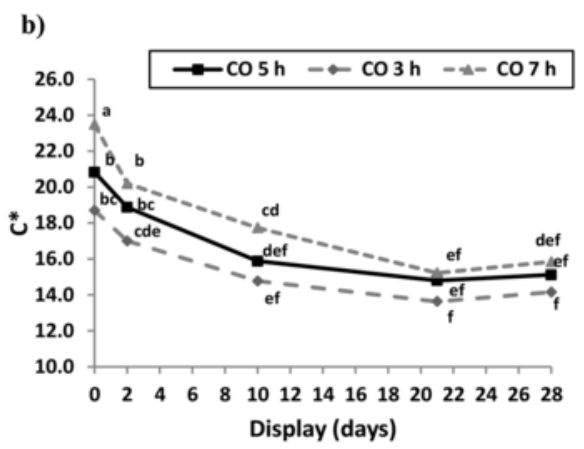

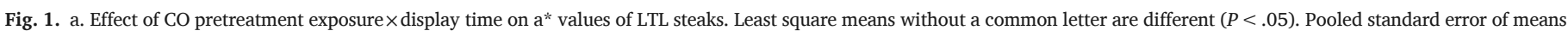

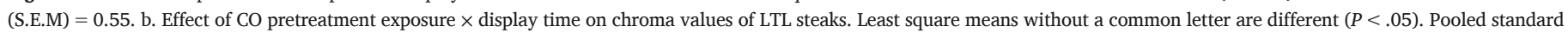
error of means (S.E.M) $=0.65$. 


\subsubsection{Reflectance ratios}

$K / S$ ratios are useful for estimating myoglobin redox forms (AMSA, 2012), and give a more detailed understanding of the colour stability of meat surfaces. Varying the exposure time to $\mathrm{CO}$ did not affect reflectance ratios for $\mathrm{DMb}(P>.05)$. However, there was a significant temperature effect $(P<.001)$ (Fig. 2 a), with the lower temperature $\left(2{ }^{\circ} \mathrm{C}\right)$ having higher values. There was also a temperature $\times$ display day interaction $(P<.01)$ due to the difference between the two storage temperatures being much greater at days 21 and 28 .

$K / S$ ratios for MMb were affected by $\mathrm{CO}$ exposure time $(P<.01)$ (Fig. 2 b) and there was a temperature $\times$ display day interaction $(P<.001)$ with the decrease being more marked at the lower temperature at days 21 and 28 (Fig. 2 c). K/S ratios of 0.58 and 1.4 represent $100 \%$ and $0 \%$ for MMb (O'Keefe \& Hood, 1980). Reflectance standards prepared according to AMSA (2012) were close to these values (0.54-1.52). MMb values decreased over the display period with the lowest values being for the lower temperature $2^{\circ} \mathrm{C}$ (1.09) at day 28 (Fig. 2 c).
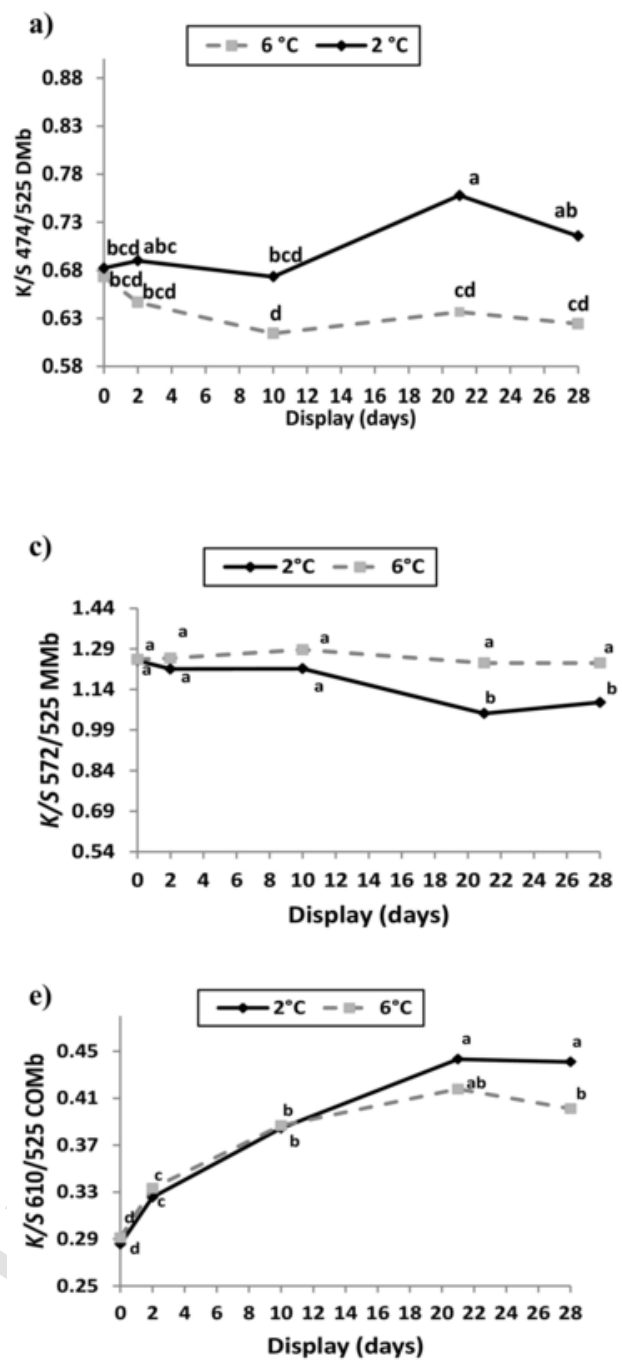

$\mathrm{CO}$ exposure time had a significant effect on $\mathrm{COMb} K / S$ values $(P<.001)$ which increased as CO exposure time increased (Fig. $2 \mathrm{~d})$ in agreement with $\mathrm{a}^{*}$ and chroma values. A temperature $\times$ display day interaction occurred for COMb $K / S$ values $(P<.001)$ (Fig. $2 \mathrm{e}$ ), with values increasing over storage duration and becoming significant at day 28. Reference standards prepared according to AMSA (2012) showed a COMb $K / S$ value of 0.16 for $100 \%$ COMb and 0.52 for $0 \%$ COMb. The increased $K / S \mathrm{COMb}$ values over storage indicate discoloration occurred as $K / S \mathrm{COMb}$ values shifted towards the $0 \% \mathrm{COMb}$ reference standard of 0.52 (Fig. 2d). These results are in agreement with the discoloration trend observed for $\mathrm{a}^{*}$ and $\mathrm{C}^{*}$ values (Fig. 1a \& 1b). This result demonstrates that discoloration occurred and it is likely that very little COMb was present for all treatments at the end of storage and indicates that CO does not mask meat spoilage thereby addressing the concerns of consumers. $K / S$ ratios are useful for estimating myoglobin redox forms, and give a more detailed understanding of the $\mathrm{CO}$ pretreated meat colour stability as very little COMb was present by day 28 .

Greene et al. (1971), reported that an increased formation of MMb in $\mathrm{CO}$ treated meat over storage is equalised with a decreased concen-
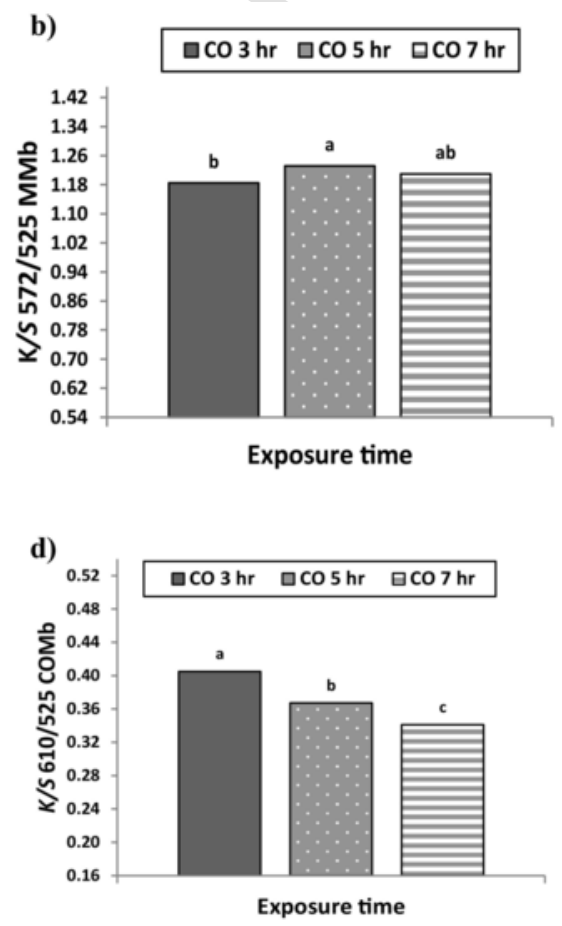

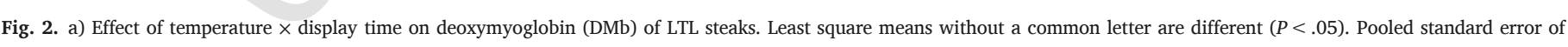

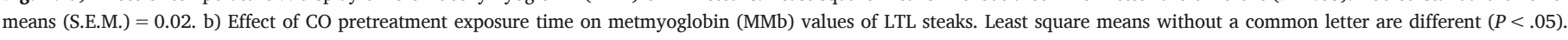

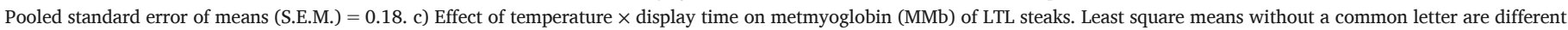

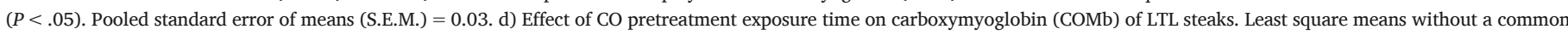

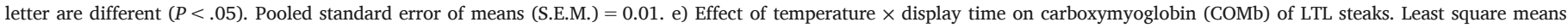
without a common letter are different $(P<.05)$. Pooled standard error of means (S.E.M. $)=0.01$. 
tration of $\mathrm{COMb}$ as is evident in this present study. Jeong and Claus (2010), reported that the COMb reflectance ratio showed similar discoloration patterns to a* values, however they also reported that reflectance ratios are not definitive of the colour changes with $\mathrm{CO}$ exposure time. This could be a possible explanation for the effect that temperature had towards the end of the storage on all $K / S$ ratio values $(P<.05)$, while it had no effect on a* and chroma values $(P>.05)$ (Fig. 1 a $\& 1$ b). On the other hand, this could indicate that $K / S$ ratios may be more sensitive than CIELAB colour parameters at monitoring discoloration during storage. A possible explanation for discoloration occurring in $\mathrm{CO}$ pretreated steaks over storage may be due to the $\mathrm{CO}$ which was bound to the myoglobin at the six co-ordinate position of the iron-porphyrin ring, disappearing over time. As a result the COMb reverts to deoxymyoglobin which is confirmed in Fig. 2 a. This conversion of $\mathrm{COMb}$ to $\mathrm{DMb}$ commences at the inner boundary of the COMb layer which represents the limit of penetration of CO. At this point the partial pressure of $\mathrm{COMb}$ would be minimal so the proportion of the myoglobin converted to $\mathrm{COMb}$ would be minimal. It follows therefore that the reversion back to DMb will progress towards the surface just as is the case with oxymyoglobin in high oxygen MAP packaged meat.

Reflectance percentages were also calculated in this present study, from $K / S$ ratios, following Stewart et al. (1965). However, unrealistic data were observed with values lower than $0 \%$ or $>100 \%$ in accordance with Mancini et al. (2003). Mancini et al. (2003), reported that transforming the data may be useful to obtain more realistic results; however no advantage was demonstrated in this study. To the authors' knowledge and Mancini et al. (2003) there has been no research supporting the benefits of transforming the data.

\section{2. $p H$}

There was no significant effect of $\mathrm{CO}$ pretreatment exposure time on pH values $(P>.05)$ (Table 1$)$. Similarly, Aspé, Roeckel, Martí, and Jiménez (2008) reported no significant difference for $\mathrm{pH}$ values when $5 \%$ CO pretreated vacuum packaged beef steaks were compared to the control (untreated vacuum package). However, both temperature $(P<.01)$ and storage day $(P<.001)$ had a significant effect on $\mathrm{pH}$ values (Table 1 ). The $\mathrm{pH}$ decreased over storage and the higher storage temperature $\left(6^{\circ} \mathrm{C}\right)$ reduced $\mathrm{pH}$ values compared to good industry practice $\left(2^{\circ} \mathrm{C}\right)$ (Table 1$)$. Increased temperature is a well-documented contributing factor which has an adverse effect on meat $\mathrm{pH}$ due to an increased rate of glycolysis forming lactic acid consequently reducing pH (Hertzman, Olsson, \& Tornberg, 1993; Mungure, Bekhit, Birch, \& Stewart, 2016).

\subsection{Purge loss}

Purge loss is also known as drip loss or water holding capacity (WHC) and can be described as a loss of water from the meat. Purge is

Table 1

Effect of display day and temperature on the $\mathrm{pH}$ values of LTL steaks stored at $2^{\circ} \mathrm{C}$ or $6^{\circ} \mathrm{C}$.

\begin{tabular}{lll}
\hline Display (days) & $\mathrm{pH}$ & S.E.M. \\
\hline 0 & $5.47^{\mathrm{ab}}$ & 0.06 \\
2 & $5.41^{\mathrm{bc}}$ & \\
10 & $5.49 \mathrm{a}$ & \\
21 & $5.41^{\mathrm{bc}}$ & \\
28 & $5.37^{\mathrm{c}}$ & 0.05 \\
Temperature $\left({ }^{\circ} \mathrm{C}\right)$ & & \\
$2^{\circ} \mathrm{C}$ & $5.45^{\mathrm{a}}$ & \\
$6^{\circ} \mathrm{C}$ & $5.41^{\mathrm{b}}$ & \\
\hline
\end{tabular}

Least square means without a common letter are different $(P<.05)$.

Temp (Temperature).

S.E.M (Pooled standard error of means). comprised of sarcoplasmic proteins, amino acids and water soluble vitamins (Huff-Lonergan, 2010). Purge loss is a particular problem in vacuum packaged meat as purge can be unattractive to the consumer and cause reduced weight loss from the meat leading to economic losses (Naththarampatha, Warner, Jacob, Beatty, \& Kerr, 2010). The results of purge loss in this study are presented in (Fig. 3a \& b). Purge loss was not affected by varying the exposure time to $\mathrm{CO}$ pretreatment $(P>.05)$ suggesting $\mathrm{CO}$ has no effect on purge loss (data not shown). This result is in agreement with previous researchers. Aspé et al. (2008), reported that a $5 \%$ CO pretreatment prior to vacuum packaging beef steaks had no effect on purge loss when compared to the control (untreated vacuum package) suggesting that $\mathrm{CO}$ has no role in preventing purge loss. Likewise, Stetzer et al. (2007) reported that CO had no effect on purge loss for beef steaks stored in either CO-MAP or high oxygen MAP. Similarly, Krause et al. (2003) showed that CO-MAP did not reduce purge loss in pork loins when compared to high oxygen MAP.

However, temperature and display day had a significant effect on all treatments $(P<.001)$ (Fig. 4a). Purge loss increased during display from $3.05 \%$ on day 0 to $5.3 \%$ on day 28 (Fig. 3b). The expected increase in purge loss over display was increased in treatments stored at $\left(6^{\circ} \mathrm{C}\right)$ (Fig. 3a). Increased temperature combined with meat ageing and lowered $\mathrm{pH}$, as evident in this study, are reported to have a negative effect on purge loss due to muscle denaturation resulting in a reduction of water holding capacity in sarcoplasmic proteins (Huff-Lonergan, 2010; Mungure et al., 2016). Sayre, Kiernat, and Briskey (1964), reported that slight increases in storage temperature from 0 to $4^{\circ} \mathrm{C}$ can contribute significantly to increased purge loss. Additionally, the higher purge loss values reported for steaks displayed at $6^{\circ} \mathrm{C}$ may be linked to lower $\mathrm{pH}$ values as WHC is reduced the closer the $\mathrm{pH}$ is to the isoelectric point of most meat proteins ( $\mathrm{pH} 5.1$ ) resulting in increased purge loss.

\section{4. $C O M b$ depth}

COMb layer increased with increased exposure $(P<.001)$ (Fig. 3 c). There was an exposure time $\times$ display day interaction with the difference in $\mathrm{CO}$ penetration depth between exposure times increasing and decreasing with display day $(P<.001)$ (Fig. 3 c). Temperature had no effect on $\mathrm{CO}$ penetration suggesting mild temperature abuse $\left(6^{\circ} \mathrm{C}\right)$ is not an influential factor to mask spoilage. The depth of the CO penetration layer diminished over storage as colour intensity decreased (Fig. $3 c$ ), corresponding to reduced redness in $\mathrm{a}^{*}, \mathrm{C}^{*}$ and $K / S \mathrm{COMb}$ values due to the reduction in $\mathrm{COMb}$. $\mathrm{CO}$ penetration depth ranged from $3.3-3.0 \mathrm{~mm}$ on day 0 and decreased to $2.1-0.00 \mathrm{~mm}$ on day 28 (Fig. 3 c). The CO5 treatment, which is the optimum treatment to induce redness, while allowing discoloration to occur by the use-by date had very little $\mathrm{CO}$ penetration thickness $(0.6 \mathrm{~mm})$ by day 28 . This supports the colour results that $\mathrm{CO}$ did not mask spoilage as the COMB layer was had virtually disappeared by the use-by date of 28 days. The $\mathrm{CO} 3$ treatment completely discoloured by day $28(0.00 \mathrm{~mm})$. A similar trend following depletion of $\mathrm{CO}$ penetration depth was reported by others (Jayasingh, Cornforth, Carpenter, \& Whittier, 2001; Sakowska, Guzek, Glabska, \& Wierzbicka, 2016). Sakowska, Guzek, Sun, and Wierzbicka (2016), investigated a range of $\mathrm{CO}$ pretreatments $(0.1 \%-0.5 \%)$ applied to beef steaks for $48 \mathrm{~h}$ prior to vacuum packaging and obtained a CO penetration depth of $0.0-2.0 \mathrm{~mm}$ after $21 \mathrm{~d}$ for $0.1 \%-0.5 \%$ CO pretreatment, respectively. Jayasingh et al. (2001) also reported that for 5\% CO pretreated vacuum packed beef steaks the COMB layer disappeared after 3 weeks storage. 

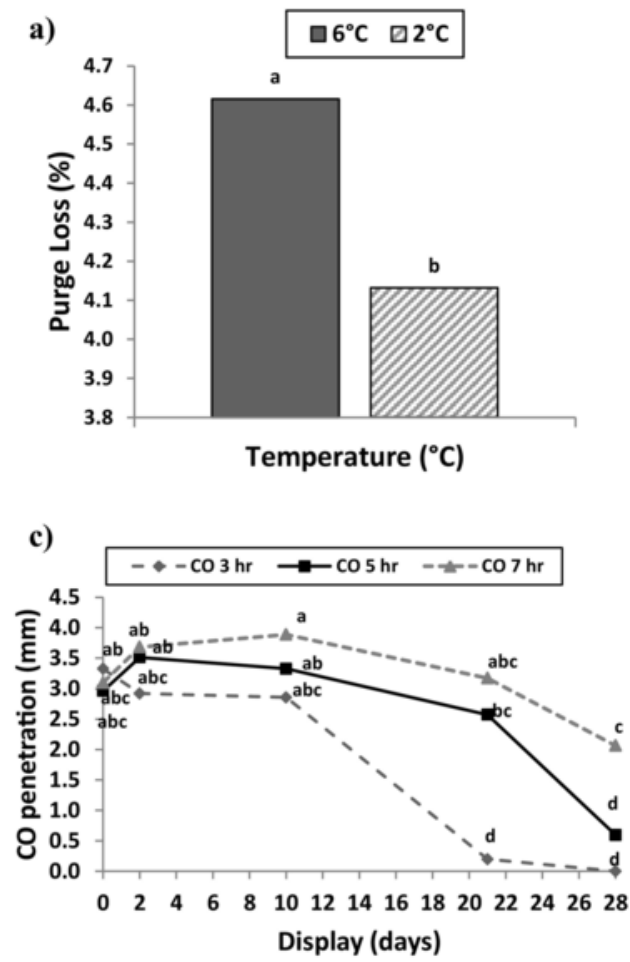
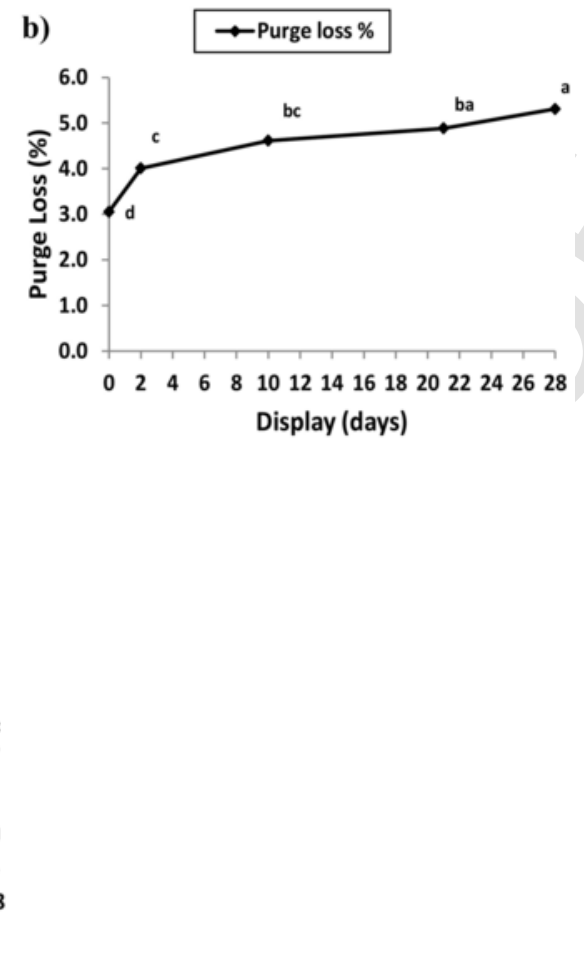

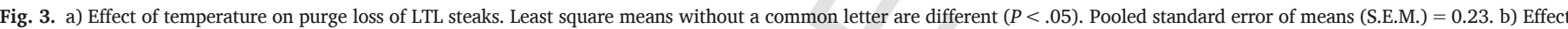

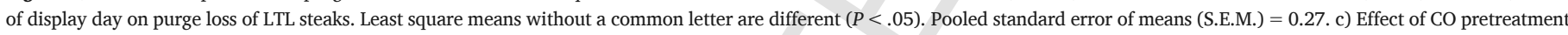
exposure time on carboxymyoglobin (COMb) layer in LTL steaks. Least square means without a common letter are different $(P<.05)$. Pooled standard error of means $($ S.E.M. $)=0.32$.

\subsection{Cooking loss}

Cooking loss may be described as the amount of moisture lost after the protein denaturation process which occurs during cooking. The results for percentage cooking loss using two separate forms of analysis (Model $1 \& 2$ ) are presented in (Tables 2 and 3). No interactions or significant differences were observed for either models when comparing the effect of exposure time to $\mathrm{CO}$ pretreatment, temperature or storage day $(P>.05)$. The mean cooking loss values for all CO pretreatment exposure times and both storage temperatures $\left(2^{\circ} \mathrm{C}\right.$ and $\left.6^{\circ} \mathrm{C}\right)$ on each day were similar to each other (Model 1) (Table 2) and to the controls (Model 2) (Table 3) $(P>.05)$. Mean cooking loss values ranged over storage from $27.5 \%$ to $29.8 \%$ on day 0 , and from $26.9 \%$ to $29.0 \%$ on day 28 (Tables 2 and 3). Results from this present study are in agreement with previous research where varying exposure time to $5 \% \mathrm{CO}$ pretreatment had no effect on cooking loss (Van Rooyen, Allen, Crawley, \& O'Connor, 2017). Therefore, varying exposure time, temperature and storage period had no effect on cooking loss.

\subsection{Warner Bratzler shear force}

The results for WBSF measurements were analysed using two separate forms of analysis (Models $1 \& 2$ ), presented in (Tables $2 \& 3$ ). The $3 \times 2 \times 5$ factorial split plot model with three exposure times $(3 \mathrm{~h}, 5 \mathrm{~h}$, $7 \mathrm{~h})$, two display temperatures $\left(2{ }^{\circ} \mathrm{C}, 6^{\circ} \mathrm{C}\right)$ and five storage times $(0 \mathrm{~d}, 2$ d, 10 d, 21 d, 28 d) showed a significant three-way interaction for exposure time $\times$ temperature $\times$ display day $(P<.01)$ with no particular

Table 2

Mean WBSF and cooking loss values of LTL steaks. Model $1 .(3 \times 2 \times 5$ factorial design).

\begin{tabular}{|c|c|c|c|c|c|c|c|c|}
\hline & & & Display (Da & & & & & \\
\hline WBSF (N) & Exposure time (h) & Temp $\left({ }^{\circ} \mathrm{C}\right)$ & 0 & 7 & 14 & 21 & 28 & S.E.M. \\
\hline \multirow{12}{*}{ Cooking Loss (\%) } & \multirow[t]{2}{*}{$\mathrm{CO} 3$} & 2 & $33.5^{\text {abcdefgh }}$ & $36.1^{\text {abcdefgh }}$ & $36.7^{\text {abcdefgh }}$ & $34.2^{\text {abcdefgh }}$ & $28.5^{\text {defgh }}$ & \multirow[t]{6}{*}{3.8} \\
\hline & & 6 & $40.7^{\text {abcde }}$ & $44.4^{\mathrm{abc}}$ & $36.2^{\text {abcdefgh }}$ & $27.4^{\mathrm{efgh}}$ & $25.6^{\mathrm{fgh}}$ & \\
\hline & CO5 & 2 & $48.7^{\mathrm{a}}$ & $46.9^{\mathrm{ab}}$ & $36.2^{\text {abcdefgh }}$ & $38.1^{\text {abcdefg }}$ & $31.9^{\text {bcdefg }}$ & \\
\hline & \multirow{3}{*}{$\mathrm{CO} 7$} & 6 & $45.8^{\mathrm{ab}}$ & $42.5^{\mathrm{abcd}}$ & $39.0^{\text {abcdefg }}$ & $26.9^{\mathrm{efgh}}$ & $28.0^{\text {defgh }}$ & \\
\hline & & 2 & $39.9^{\text {abcdef }}$ & $47.3^{\mathrm{a}}$ & $39.0^{\text {abcdefg }}$ & $24.2^{\mathrm{gh}}$ & $28.0^{\text {defgh }}$ & \\
\hline & & 6 & $47.2^{\mathrm{ab}}$ & $39.8^{\text {abcdef }}$ & $30.3^{\text {cdefgh }}$ & $23.1^{\mathrm{h}}$ & $26.7^{\mathrm{efgh}}$ & \\
\hline & \multirow[t]{2}{*}{$\mathrm{CO} 3$} & 2 & 28.2 & 26.4 & 30.0 & 28.5 & 29.0 & \multirow[t]{6}{*}{2.0} \\
\hline & & 6 & 27.9 & 26.6 & 29.6 & 29.7 & 28.6 & \\
\hline & \multirow[t]{2}{*}{$\mathrm{CO} 5$} & 2 & 29.8 & 29.1 & 29.2 & 29.1 & 27.7 & \\
\hline & & 6 & 27.5 & 27.4 & 29.2 & 27.1 & 27.9 & \\
\hline & \multirow[t]{2}{*}{$\mathrm{CO} 7$} & 2 & 28.3 & 27.0 & 28.0 & 32.1 & 29.0 & \\
\hline & & 6 & 28.5 & 27.9 & 28.7 & 25.6 & 27.0 & \\
\hline
\end{tabular}

Least square means without a common letter are different $(P<.05)$.

Temp (Temperature).

S.E.M. (Pooled standard error of means). 
Table 3

Mean WBSF and cooking loss values of LTL steaks. Model 2 . $(6 \times 2 \times 2$ factorial design).

\begin{tabular}{|c|c|c|c|c|c|c|c|}
\hline \multirow[b]{3}{*}{ Treatment } & \multirow[b]{3}{*}{ Temp $\left({ }^{\circ} \mathrm{C}\right)$} & \multicolumn{3}{|c|}{ WBSF (N) } & \multicolumn{3}{|c|}{ Cooking Loss (\%) } \\
\hline & & \multicolumn{6}{|c|}{ Display (Days) } \\
\hline & & 0 & 28 & S.E. & 0 & 28 & S.E.M. \\
\hline \multirow[t]{2}{*}{ CONT3 } & 2 & $41.2^{\mathrm{ab}}$ & $28.8^{\mathrm{b}}$ & 6.12 & 29.8 & 28.1 & 1.62 \\
\hline & 6 & $39.6^{\mathrm{ab}}$ & $30.0^{\mathrm{ab}}$ & & 28.7 & 27.4 & \\
\hline \multirow[t]{2}{*}{ CONT5 } & 2 & $46.9^{\mathrm{ab}}$ & $27.6^{\mathrm{b}}$ & & 29.1 & 27.8 & \\
\hline & 6 & $46.4^{\mathrm{ab}}$ & $25.3^{\mathrm{b}}$ & & 28.1 & 28.3 & \\
\hline \multirow[t]{2}{*}{ CONT7 } & 2 & $53.0^{\mathrm{a}}$ & $26.8^{\mathrm{b}}$ & & 29.7 & 27.4 & \\
\hline & 6 & $49.0^{\mathrm{ab}}$ & $28.2^{\mathrm{b}}$ & & 27.8 & 26.9 & \\
\hline \multirow[t]{2}{*}{$\mathrm{CO} 3$} & 2 & $31.9^{\mathrm{ab}}$ & $28.5^{\mathrm{b}}$ & & 28.2 & 29.0 & \\
\hline & 6 & $40.7^{\mathrm{ab}}$ & $25.6^{\mathrm{b}}$ & & 27.8 & 28.6 & \\
\hline \multirow[t]{2}{*}{$\mathrm{CO} 5$} & 2 & $48.7^{\mathrm{ab}}$ & $31.9^{\mathrm{ab}}$ & & 29.8 & 27.7 & \\
\hline & 6 & $45.8^{\mathrm{ab}}$ & $28.0^{\mathrm{b}}$ & & 27.5 & 27.9 & \\
\hline \multirow[t]{2}{*}{$\mathrm{CO} 7$} & 2 & $39.9^{\mathrm{ab}}$ & $28.0^{\mathrm{b}}$ & & 28.3 & 29.0 & \\
\hline & 6 & $48.1^{\mathrm{ab}}$ & $26.7^{\mathrm{b}}$ & & 28.5 & 27.0 & \\
\hline
\end{tabular}

Least square means without a common letter are different $(P<.05)$.

Temp (Temperature).

S.E.M. (Pooled standard error of means).

pattern observed (Table 2). This suggests that even though samples were from the same breed, sex and age group and statistical blocking of loins and randomisation within loins were applied; variability between steaks which is not uncommon in meat may have obscured any trends. In contrast, in the $6 \times 2 \times 2$ factorial split plot model with six pretreatments (CONT3, CONT5, CONT7, CO3, CO5, CO7), two display temperatures $\left(2{ }^{\circ} \mathrm{C}, 6^{\circ} \mathrm{C}\right)$ and two storage times $(0 \mathrm{~d}, 28 \mathrm{~d})$, there was no effect of pretreatment, storage temperature or their interaction $(P>.05)$ (Table 3 ). This result is in agreement with previous findings by Van Rooyen, Allen, Crawley, and O'Connor (2017) that varying exposure time to CO pretreatment had no effect on meat tenderness $(P>.05)$. Likewise Sakowska, Guzek, Sun, and Wierzbicka (2016) reported no differences $(P>.05)$ in WBSF values when comparing $0.5 \%$ CO pretreated beef steaks to vacuum packed or CO-MAP beef steaks after $21 \mathrm{~d}$ storage, suggesting $\mathrm{CO}$ had very little effect on tenderness.

A significant storage day effect occurred $(P<.001)$ for both models (Tables $2 \& 3$ ) as expected due to the wet ageing process (vacuum packaging) and increase in proteolysis. Ageing is also known to remove a lot of the variation between samples which was also evident in both models as WBSF values were similar for all treatments (Table 2) or relative to the controls (Table 3) by display day 28 for $2{ }^{\circ} \mathrm{C}$ and $6{ }^{\circ} \mathrm{C}$. All WBSF means on day 28 (Tables $2 \& 3$ ) would be considered 'very tender' $(31.4 \mathrm{~N})$ or 'tender' $(31.4 \mathrm{~N}-38.2 \mathrm{~N})$ (Belew, Brooks, McKenna, \& Savell, 2003). These low WBSF values are attributed to the 34-36 d vacuum ageing period the samples experienced (6-8 d sub primal vacuum ageing postmortem prior to CO pretreatment, followed by $28 \mathrm{~d}$ individual vacuum packed display period). Temperature had no effect $(P>.05)$ on WBSF with either the $3 \times 2 \times 5$ or the $6 \times 2 \times 2$ factorial split plot model (Tables $2 \& 3$ ) $(P>.05)$. In summary, the application of CO-pretreatment or mild temperature abuse had no negative effect on meat tenderness $(P>.05)$.

\section{Conclusion}

In summary, increasing the $\mathrm{CO}$ pretreatment exposure time of LTL steaks enhanced colour stability. All treatments discoloured over storage irrespective of display temperature, and therefore meat spoilage would not be masked, thus addressing consumer concerns about safety and ensuring the consumer of a reliable visual indication of freshness. A CO-pretreatment of $5 \mathrm{~h}$ is the optimum exposure time to induce colour stability while allowing discoloration to occur by a use-by date of $28 \mathrm{~d}$. Surface reflectance ratios are useful for estimating myoglobin redox forms and may give a more detailed understanding of $\mathrm{CO}$ pretreated meat colour stability, as similar trends between $\mathrm{a}^{*}$ and $\mathrm{C}^{*}$ values were observed. Additionally, surface reflectance ratios confirmed that CO does not mask spoilage, since very little COMb was present by day 28. Temperature had no effect on $\mathrm{a}^{*}$ and $C^{*}$ values, while it did affect the $K / S$ values after 21 and 28 days suggesting that $K / S$ ratios could be more sensitive than colour parameters at monitoring discoloration. The depth of the COMb layer also reduced during storage and corresponded to colour parameters and surface reflectance ratios. Exposure to $\mathrm{CO}$ pretreatment did not have any negative effect on meat quality attributes, while mild temperature abuse $\left(6^{\circ} \mathrm{C}\right)$ increased $\mathrm{pH}$ and purge loss as expected. Therefore this study confirms that CO-pretreatment does not mask meat spoilage.

The results from this present study combined with a recent article by Van Rooyen, Allen, and O'Connor (2017) outlining recent research findings which warrant the re-evaluation of $\mathrm{CO}$ being permitted as a packaging gas within the EU show that applying 5\% CO pretreatments may be a potential innovative solution to current packaging issues within the meat sector.

\section{Uncited reference}

Hunt et al., 2004

\section{Acknowledgements}

Lauren-Anne Van Rooyen is in receipt of a Teagasc Walsh Fellowship. The authors would like to acknowledge the Department of Agriculture, Food and the Marine (DAFM) for their financial support through the Food Institutional Research Measure (FIRM) (project 11/F/060). The authors would also like to thank Paula Reid for her statistical assistance and Eugene Vessey for his butchery skills.

\section{References}

AMSA, 1995. Research guidelines for cookery, sensory evaluation and instrumental tenderness measurements of fresh meat.

AMSA, 2012. In: A. M. S. Association (Ed.), Meat Colour Measurement Guidelines. pp. 1-109, (Champaign, Illinois, USA).

Aspé, E., Roeckel, M., Martí, M.C., Jiménez, R., 2008. Effect of pre-treatment with carbon monoxide and film properties on the quality of vacuum packaging of beef chops. Packaging Technology and Science 21 (7), 395-404.

Belew, J.B., Brooks, J.C., McKenna, D.R., Savell, J.W., 2003. Warner-Bratzler shear evaluations of 40 bovine muscles. Meat Science 64 (4), 507-512.

European Commission, 2001. Opinion of the Scientific Committee on Food on the use of carbon monoxide as component of packaging gases in modified atmosphere packaging. 
FAO, 2016. SAVE FOOD: Global initiative on food loss and waste reduction.

Faustman, C., Cassens, R.G., 1990. The biochemical basis for discoloration in fresh meat: A review. Journal of Muscle Foods 217-243.

2004. Letter from Tarantino, L. to Kushner, G.J. In: FDA, FDA (Eds.), Re: GRAS Notice No. GRN 000143.

Federal Register of Legislative Instruments, 2014. Australia New Zealand food standards code - standard 1.3.3 - processing aids. In: F. R. O. L. Instruments (Ed.), F2014C00795 (Vol. Standard 1.3.3). Agency, pp. 1-25.

Grebitus, C., Jensen, H.H., Roosen, J., 2013. US and German consumer preferences for ground beef packaged under a modified atmosphere - Different regulations, different behaviour?. Food Policy 40, 109-118.

Greene, B.E., Hsin, I.M., Zipser, M.W., 1971. Retardation of oxidative color changes in raw ground beef. Journal of Food Science 36, 940-942.

Hertzman, C., Olsson, U., Tornberg, E., 1993. The influence of high temperature, type of muscle and electrical stimulation on the course of rigor, ageing and tenderness of beef muscles. Meat Science 35 (1), 119-141.

Huff-Lonergan, E., 2010. Water-holding capacity of fresh meat: National Pork Board/ American meat science association fact sheet.

Hunt, M.C., Mancini, R.A., Hachmeister, K.A., Kropf, D.H., Merriman, M., DelDuca, G., Milliken, G., 2004. Carbon monoxide in modified atmosphere packaging affects color, shelf life, and microorganisms of beef steaks and ground beef. Journal of Food Science 69 (1), C45-C52.

Issanchou, S., 1996. Consumer expectations and perceptions of meat and meat product quality. Meat Science 43 (Suppl. 1), 5-19.

Jayasingh, P., Cornforth, D.P., Carpenter, C.E., Whittier, D., 2001. Evaluation of carbon monoxide treatment in modified atmosphere packaging or vacuum packaging to increase color stability of fresh beef. Meat Science 59 (3), 317-324.

Jeong, J.Y., Claus, J.R., 2010. Color stability and reversion in carbon monoxide packaged ground beef. Meat Science 85 (3), 525-530.

Krause, T.R., Sebranek, J.G., Rust, R.E., Honeyman, M.S., 2003. Use of carbon monoxide packaging for improving the shelf life of pork. Journal of Food Science 68 (8), 2596-2603.

Krzywicki, K., 1979. Assessment of relative content of myoglobin, oxymyoglobin and metmyoglobin at the surface of beef. Meat Science 3, 1-10.

MacDougall, D.B., Down, N.F., Taylor, A.A., 1986. Colour stability of vacuum skin packed frozen beef. In: Paper presented at the proceedings European meeting of meat research workers, Bulgaria.

Mancini, R.A., Hunt, M.C., Kropf, D.H., 2003. Reflectance at 610 nanometers estimates oxymyoglobin content on the surface of ground beef. Meat Science 64 (2), 157-162.

Mungure, T.E., Bekhit, A.E.-D.A., Birch, E.J., Stewart, I., 2016. Effect of rigor temperature, ageing and display time on the meat quality and lipid oxidative stability of hot boned beef semimembranosus muscle. Meat Science 114, 146-153.
Naththarampatha, A.N., Warner, R.D., Jacob, R.H., Beatty, D.T., Kerr, M.G., 2010. Effect of rigor temperature on purge and colour of beef loin using the filter paper method to measure purge. In: Paper presented at the Proc. Aust. Soc. Prod.

O'Keefe, M., Hood, D.E., 1980. Anoxic storage of fresh beef: Colour stability and weight loss. Meat Science 5, 267-281.

Raines, C.R., Hunt, M.C., 2010. Headspace volume and percentage of carbon monoxide affects Carboxymyoglobin layer development of modified atmosphere packaged beef steaks. Journal of Food Science 75 (1), C62-C65.

Sakowska, A., Guzek, D., Glabska, D., Wierzbicka, A., 2016. Carbon monoxide concentration and exposure time effects on the depth of $\mathrm{CO}$ penetration and surface color of raw and cooked beef longissimus lumborum steaks. Meat Science 121, 182-188.

Sakowska, A., Guzek, D., Sun, D.W., Wierzbicka, A., 2016. Effects of 0.5\% carbon monoxide in modified atmosphere packagings on selected quality attributes of M. Longissimus dorsi beef steaks. Journal of Food Process Engineering 1-10.

Sayre, R.N., Kiernat, B., Briskey, E.J., 1964. Processing characteristics of porcine muscle related to $\mathrm{pH}$ and temperature during rigor mortis development and to gross morphology $24 \mathrm{hr}$ post-Mortema,b,c. Journal of Food Science 29 (2), 175-181.

Shackelford, S.D., Koohmaraie, M., Whipple, G., Wheeler, T.L., Miller, M.F., Crouse, J.D., Reagan, J.O., 1991. Predictors of beef tenderness; development and verification. Journal of Food Science 56 (5), 1130-1135.

Stetzer, A.J., Wicklund, R.A., Paulson, D.D., Tucker, E.M., Macfarlane, B.J., Brewer, M.S., 2007. Effect of carbon monoxide and high oxygen modified atmosphere packaging (MAP) on quality characteristics of beef strip steaks. Journal of Muscle Foods 18 (1), 56-66.

Stewart, M.R., Zipser, M.W., Watt, B.M., 1965. The use of reflectance spectrophotometry for the assay of raw pigments. Journal of Food Science 30, 487-491.

USDA-FSIS (Producer), 2016, Jan 29. Export requirements for Canada. Retrieved from http://www.fsis.usda.gov/wps/portal/fsis/topics/international-affairs/ exporting-products/export-library-requirements-by-country/Canada.

Van Rooyen, L.A., Allen, P., Crawley, S.M., O'Connor, D.I., 2017. The effect of carbon monoxide pretreatment exposure time on the colour stability and quality attributes of vacuum packaged beef steaks. Meat Science 129, 74-80.

Van Rooyen, L.A., Allen, P., O'Connor, D.I., 2017. The application of carbon monoxide in meat packaging needs to be re-evaluated within the EU: An overview. Meat Science 132, 179-188.

Wheeler, T.L., Shackelford, S.D., Koohmaraie, M., 1997. Standardizing collection and interpretation of warner-bratzler shear force and sensory tenderness data. In: Paper presented at the Proc. Recip. Meat Conf. 